UDC 621.039.058

O.S. Mazurok

Odessa National Polytechnic University, 1 Shevchenko Ave., Odessa, Ukraine, 65044; e-mail: mazuroksasha@gmail.com

\title{
THERMAL HYDRAULIC ANALYSIS OF THE REGIMES WITH UNMANAGEABLE CONTROL RODS MOVEMENT AND EJECTION FOR THE REACTOR STRENGTH ESTIMATION
}

\begin{abstract}
О.С. Мазурок. Теплогідравлічний аналіз режимів з некерованим рухом і викидом органів регулювання для оцінки міцності реактора. У статті представлені результати дослідження (теплогідравлічного аналізу) вихідних подій (регламентних режимів), пов'язаних з некерованим рухом і викидом ОР СУЗ, які раніше кількісно не розглядалися в рамках оцінки термоудару і циклічної міцності корпусу і внутрішньокорпусних пристроїв реактора, а тільки якісно. Метою дослідження $є$ попередня оцінка впливу даних режимів на елементи реактора, підготовка граничних умов для подальшої оцінки міцності, на підставі чого буде зроблено остаточний висновок. Дослідження має наукову і практичну значимість, так як неврахування даних режимів може призвести до спотворення результатів, на підставі яких приймається рішення щодо можливості продовження терміну служби реакторів типу BBEP-1000. Дослідження виконано шляхом виконання розрахункового аналізу з використанням коду RELAP5/Mod3.2. При цьому застосований консервативний підхід до вибору початкових і граничних умов, враховані рекомендації МАГАТЕ. Розрахунковий аналіз показав, що розглянуті вихідні події є представницькими і повинні бути враховані при продовженні експлуатації ВВЕР-1000, однак, для підтвердження цього потрібно виконати аналіз міцності.

Ключові слова: Теплогідравлічний аналіз, ОР СУЗ, реактор, термін служби, корпус, ВКП

O.S. Mazurok. Thermal hydraulic analysis of the regimes with unmanageable control rods movement and ejection for the reactor strength estimation. The article presents results of research (thermal-hydraulic analysis) of initiating events (regulatory regimes), associated with the uncontrolled movement and ejection of control rods that had previously not been considered quantitatively in the evaluation of thermal shock and cyclic strength of the reactor vessel and internals. The purpose of the research is preliminary evaluation of the influence selected regimes to the reactor components, preparation of boundary conditions for further strength analysis, based on which will make the final conclusion about the impact of these regimes. Research has a scientific and practical significance, because neglect of these conditions can lead to a distortion of the calculations results on the basis of which a decision on the possibility of extending the service life of VVER1000 was made. The research was conducted by performing a computational analysis using code RELAP5/Mod3.2. In accordance to IAEA recommendations in this case conservative approach is applied to the selection of initial and boundary conditions. Calculation analysis showed that the considered initial events are representative and should be considered in VVER-1000 life extension, but strength analysis is required for confirmation

Keywords: thermal hydraulic analysis, control rods, reactor, lifetime, vessel, internals
\end{abstract}

Introduction. The importance for ensuring strength and resources of the NPPs reactors is largely determined by their increasing role in energy supply. In February 2017, the proportion of nuclear energy in the overall energy balance approached $60 \%$. Thus life extension and assessment of the reactor strength should be seen as one of the most important directions of the power unit resource increase in general.

During reactor operation temperature and pressure (as the main design parameters) vary significantly, making essentially the load of the reactor elements not only static, but also cyclic with different speeds of reactor and internals load for various operation modes.

The cyclical character of the reactor elements load cause by the corresponding normal operation mode, as well as possible violations of normal operations mode and emergency situations, during of which is cyclical load to reactor elements by mechanical, thermal and hydrodynamic efforts, which can lead to cracks in welds, corrosion-resistant surfacing, internals mounts etc.

The formation and growth of cracks, mechanical properties changes in reactor elements structural materials (such as the reactor pressure vessel (RPV) during neutron irradiation) in reactor facility (RF) operation could lead to integrity disruption. It is in fact, is a potentially dangerous phenomenon in terms of safe RF operation as a whole. 
Thus, regulations modes those are potentially dangerous for the reactor integrity should not be overlooked. The article presents the research results of influence to reactor components of two modes that require further evaluation. These modes are caused by uncontrolled control rods (CR) movement and ejection of reactor control and protection system (RCPS).

For evaluation as the pilot units with VVER-1000 the unit № 3 of Rivne NPP was selected, because the thermal-hydraulic model for this unit is one of the most pressing. At the time of article writing it corresponds to the real condition.

\section{Analysis of the latest research and publications}

Based on the above, for the prolongation term of normal operation mode, violations of normal operations mode and emergency situations should be analyzed by performing of series of thermalhydraulic and strength calculation analysis. Thus should be considered a conservative approach taking into account recommendations by IAEA [1]. Such analyzes are typical for lifetime extension of the nuclear units worldwide, including Ukraine.

At the beginning of 2017 works on VVER-1000 lifetime extending have been performed (or at the stage implementation) at unit № 1, 2 of South Ukrainian NPP, unit № 1 - 4 Zaporizhzhya NPP, unit № 3 RNPP and in the near future will be conducted at unit №3 SUNPP and unit №1 Khmelnitsky NPP. These works are research, results of which are produced technical reports and result of which is a decision to extend the lifetime of reactors and power units in general.

At the same, some modes are considered qualitatively because of their unrepresentative character or in the case of selection of more relevant conservative mode. Some of regimes consider quantitatively if it is determined that they are characterized by factors that cause increased load on the reactor elements.

These factors are the following: rapid change of temperature; low final temperature of reactor elements (combined with high initial temperature); low flow rate or flow stagnant in the circulation loops, to which are connected the pipes of the emergency core cooling system (ECCS): in this case possible stratification and flows of cold water into the reactor; inhomogeneous temperature field in the reactor elements the most unfavorable condition, when the minimum temperature in one area combined with maximum average temperatures; large in homogeneity of heat transfer conditions in internal and external surfaces of reactor components (maximum heat transfer coefficient in the "cold" zone combined with a minimum value of heat transfer coefficient in the rest of the equipment); hydrodynamic effect, due to rapid changes in flow rate (speed) of coolant in the reactor tract.

The qualitative analysis is based on information provided in the operating documentation, as well as of earlier calculation transient analysis for this or a similar unit.

To select the type of analysis the impact of the above factors is reduced to a qualitative analysis and grouping by the following three groups [2]. The first group (1) is modes that cause large changes of temperature $\Delta T>40{ }^{\circ} \mathrm{C}$ or pressure $\Delta P>2 \mathrm{MPa}$ on the reactor elements; the second group (2) is modes that cause small changes of temperature and pressure on the reactor elements and the third group (3) is modes that cause large changes of pressure or temperature in reactor elements in local areas.

This approach has been used as part of the life extension of power units with VVER-1000 operated in Ukraine. The maximum attention was given to the impact mode relative to the RPV, and was not paid due attention to the several modes with uncontrollable movement and ejection RCPS control rods that influence to the strength of the reactor.

Publications, which studied the above modes, focused on the analysis of the reactivity effects in the core mainly. Publications in which these regimes studied relative to the effect of thermal shock and cyclic strength, in the public access is not available.

Research purpose. Research purpose is a preliminary assessment of the impact of these modes to reactor components (RPV and internals), preparation of boundary conditions (BC) for further strength evaluation, for which the final conclusion about the impact of these modes will be made.

Calculation model. For the calculation analysis we used 4-loops model of the RNPP’s unit № 3 for code RELAP5/Mod3.2 [3], which was validated by the example of the incident that took place in 22.09.2009. The incident is related to the non-closing of the main safety valve of the YP21S01 during the scheduled inspection by increasing the pressure in the primary circuit before starting up the power 
unit № 3 after the maintenance due to the jamming in the valve seat of the impulse valve YP21S04 after its opening. For the analysis of the initial event (IE), "CR RCPS ejection during the drive cover break", an element of the type of valve is attached to the upper part of the hydraulic element that simulates the space under the reactor cover. This element simulates the leak valve (diameter $55 \mathrm{~mm}$ and 85 $\mathrm{mm}$ ) and is connected to an element of the type tmdvol, which is a model of space in the hermetic valve with the corresponding parameters.

Selection of scenarios. Calculation analysis done for the following regulations modes [4]: mode 2.5 "Uncontrolled CR RCPS movement from the core" (related to normal operation modes) and mode 3.6 "CR RCPS ejection during the drive cover break" (related to emergency situations). For each mode was performed calculation of the two scenarios.

For mode 2.5 two scenarios with different operation algorithm of emergency feed water pump (EFWP) were considered. The first scenario is EFWP design algorithm and the second scenario is algorithm without EFWP startup signal due to reliable power sections blackout. For mode 3.6 two scenarios with different leak conditional diameters were considered: $55 \mathrm{~mm}$ (scenario 1) and $85 \mathrm{~mm}$ (scenario 2).

Selection of initial and boundary conditions For the calculation analysis conservative initial and boundary conditions were selected. Table1 contains the RF basic parameters values obtained by a steady-state calculating for the considered scenarios.

Table 1

Initial conditions

\begin{tabular}{|c|c|c|c|c|c|}
\hline \multirow{3}{*}{ Parameter } & \multirow{3}{*}{$\begin{array}{l}\text { Unit of } \\
\text { measur } \\
\text { ement }\end{array}$} & \multicolumn{4}{|c|}{ Parameters values $[5,6,7]$} \\
\hline & & \multicolumn{2}{|c|}{$\begin{array}{l}\text { Uncontrolled CR RCPS } \\
\text { movement from the core }\end{array}$} & \multicolumn{2}{|c|}{$\begin{array}{l}\text { CR RCPS ejection during the } \\
\text { drive cover break }\end{array}$} \\
\hline & & $\begin{array}{l}\text { Reference } \\
\text { value }\end{array}$ & Calculated value & Reference value & $\begin{array}{c}\text { Calculated } \\
\text { value }\end{array}$ \\
\hline Thermal reactor power & MW & $\begin{array}{c}3000 \pm 60 \pm 60 \\
(100 \pm 2.0 \pm 2.0) \\
\end{array}$ & 3120 (104) & - & $3(0.1)$ \\
\hline $\begin{array}{l}\text { Coolant pressure at the } \\
\text { reactor outlet }\end{array}$ & $\mathrm{kgf} / \mathrm{cm}^{2}$ & $158 \div 162$ & 162 & $\begin{array}{c}\text { From } \\
\text { Ps }\left(\mathrm{T}_{\text {hot_leg }}+20\right) \\
\text { to } 162\end{array}$ & 162 \\
\hline $\begin{array}{l}\text { Coolant level in } \\
\text { pressurizer }\end{array}$ & $\mathrm{m}$ & $\begin{array}{c}\text { Hnom( } \mathrm{T} \text { average } \\
\text { _primary }) \\
\pm 150 \mathrm{~mm} \\
\pm 150 \mathrm{~mm} \\
\end{array}$ & 8.47 & $\begin{array}{l}\text { Not less } \\
\text { Hnom( }(\mathrm{T} \text { average_pr } \\
\text { imary }) \pm 150 \mathrm{~mm}\end{array}$ & 5.4 \\
\hline $\begin{array}{l}\text { Coolant volumetric flow } \\
\text { through the reactor }\end{array}$ & $\mathrm{m}^{3} / \mathrm{h}$ & $\begin{array}{r}+4000 \\
84800^{-4800}\end{array}$ & 80001 & $\begin{array}{r}+4000 \\
84800^{-4800} \\
\end{array}$ & 80000 \\
\hline $\begin{array}{l}\text { Coolant pressure at the } \\
\text { reactor outlet }\end{array}$ & ${ }^{\circ} \mathrm{C}$ & 320 & 322 & More 260 & 280 \\
\hline $\begin{array}{l}\text { Pressure in the steam } \\
\text { generator (SG) }\end{array}$ & $\mathrm{kgf} / \mathrm{cm}^{2}$ & $60 \div 66$ & $65.85 \div 66.0$ & $47 \div 64$ & $64.5 \div 64.6$ \\
\hline Water level in SG & $\mathrm{m}$ & $0.270 \pm 0.05$ & $0.220 \div 0.235$ & $0.270-0.075$ & $0.210 \div 0.220$ \\
\hline
\end{tabular}

Table 2 shows the boundary conditions (assumptions and approval) taken at calculation scenarios modeling.

Uncontrolled CR RCPS movement from the core. This IE is considered as uncontrolled CR RCPS regulating group movement with a working speed due to the functioning violation of the RCPS group and individual control.

IE leads to the uncontrolled increase of reactor power due to the input of positive reactivity and thus to increase the fuel temperature, coolant temperature and primary/secondary pressure.

Given the fact that the APR, LPR, PP-1, PP-2 and APP during their functions performing affect to the regulating group at first, these systems are considered unable to work during accidental process. 
Boundary conditions

\begin{tabular}{|c|c|c|}
\hline $\begin{array}{l}\text { Event/ System/ } \\
\text { Equipment }\end{array}$ & $\begin{array}{l}\text { Uncontrolled CR RCPS movement from } \\
\text { the core }\end{array}$ & $\begin{array}{l}\text { CR RCPS ejection during the drive } \\
\text { cover break }\end{array}$ \\
\hline IE & $\begin{array}{l}\text { Uncontrolled CR RCPS regulating group } \\
\text { movement with a working speed due to } \\
\text { the functioning violation of the RCPS } \\
\text { group and individual control }\end{array}$ & $\begin{array}{l}\text { Scenario 1: Leak formation from under } \\
\text { reactor lid with a diameter } 55 \mathrm{~mm} \text {. } \\
\text { Scenario 2: Leak formation from under } \\
\text { reactor lid with a diameter } 85 \mathrm{~mm} \\
\text { (during cover break conservatively } \\
\text { expected ejection all cover internal } \\
\text { elements) }\end{array}$ \\
\hline Blackout & At the time of SCRAM activation & At the time of IE \\
\hline $\begin{array}{l}\text { Main circulation pumps } \\
\text { (MCP) }\end{array}$ & \multicolumn{2}{|c|}{ IE occurs when using the four MCP } \\
\hline RCPS & $\begin{array}{l}\text { Automatic power regulator (APR), limit } \\
\text { power regulator (LPR), first and second } \\
\text { kind preventive protection (PP-1, PP-2), } \\
\text { accelerated preventive protection (APP) } \\
\text { were not considered }\end{array}$ & $\begin{array}{l}\text { Reactor power increasing at the time } \\
\text { of CR RCPS ejection is not consi- } \\
\text { ?ered, because the unit is in a } \\
\text { shutdown mode: all CR RCPS are at } \\
\text { the lower limit switch, in the primary } \\
\text { formed stop concentration of boric } \\
\text { acid }\end{array}$ \\
\hline SG feeding system & $\begin{array}{c}\text { Auxiliary feed water pump (AFWP) not } \\
\text { considered. Scenario 1: EFWP design } \\
\text { algorithm is considered. Scenario 2: } \\
\text { EFWP startup signal due to reliable } \\
\text { power sections blackout is not } \\
\text { considered }\end{array}$ & Regular work \\
\hline ECCS & \multicolumn{2}{|c|}{$\begin{array}{l}\text { ECCS maximum configuration is modelled. Transport delay at the beginning of } \\
\text { the water feeding by pump is not included. Minimum values of cooling water } \\
\text { temperature are selected }\end{array}$} \\
\hline $\begin{array}{c}\text { Injection system to } \\
\text { pressurizer }\end{array}$ & \multicolumn{2}{|c|}{ Not considered conservatively } \\
\hline $\begin{array}{l}\text { Make-up\&Let-down } \\
\text { system } \\
\end{array}$ & \multicolumn{2}{|c|}{ Not considered conservatively } \\
\hline $\begin{array}{c}\text { Protection against } \\
\text { primary overpressure }\end{array}$ & \multicolumn{2}{|c|}{ Regular work } \\
\hline
\end{tabular}

Reactor power increasing during the accidental process is limited by SCRAM at reaching the setpoint on increasing of the neutron capacity of more than $107^{+2} \%$ of the nominal. Working group uncontrolled movement stops and with other CR RCPS group there is falling down. Reactor power reduces to the residual energy discharge level, the secondary pressure reduces to set point of turbine stop valves (TSV) closing and further supported by secondary steam discharging devices (SSDD).

Maintaining of primary pressure during accidental process is carried by pressure regulators. Secondary pressure increasing after TSV closing limited by SSDD functionality.

The unit blackout leads to SG feeding by emergency feed water system that provides more cooling. Not considered AFWP operation that allows to reduce the time to start emergency water feeding with temperature $5{ }^{\circ} \mathrm{C}$.

To perform the evaluation and BC receiving for strength analysis two calculation scenarios considered. In Scenario 1 EFWP design algorithm considered. In Scenario 2 the algorithm was modified to obtain more representative results (accordance with modified algorithm the emergency feed water feeding starts at SG-2.4 level decrease to $2.05 \ldots 2.15 \mathrm{~m}$, and at SG-1.3 level - to 2.05...2.15 m). 
Ignoring of signal leads to a level reduction in all SG to a value $1.35 \mathrm{~m}$ and their subsequent filling by emergency feed water with a temperature of $5{ }^{\circ} \mathrm{C}$. The above assumption allows to get deeper coolant temperature reduction, as compared to Scenario 1.

Figure $1-4$ show pressure and temperature graphs in reactor volumes for the two analyzed scenarios.

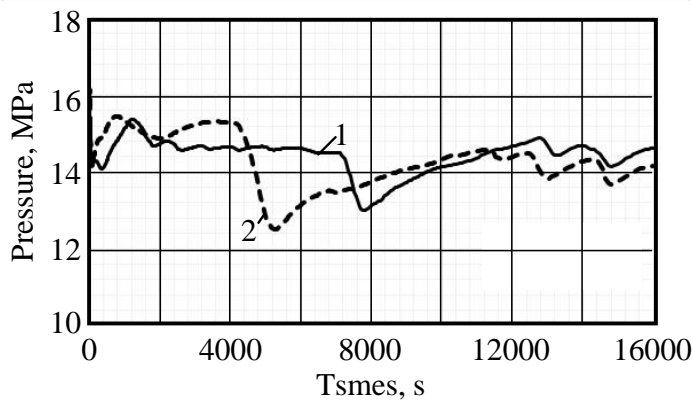

Fig. 1. Coolant pressure under the reactor lid: Scenario 1 (1); Scenario 2 (2)

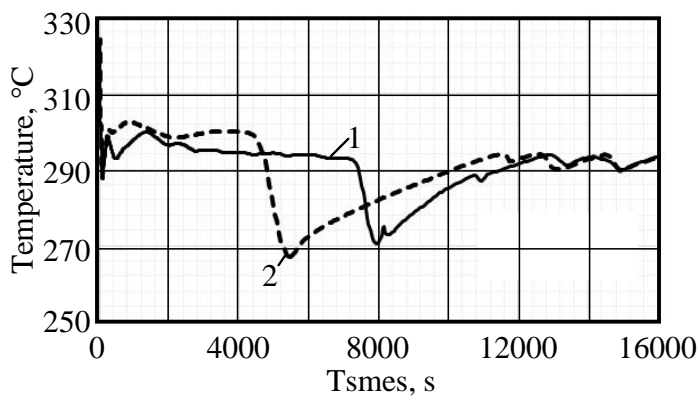

Fig. 3. Coolant temperature at the reactor outlet: Scenario 1 (1); Scenario 2 (2)

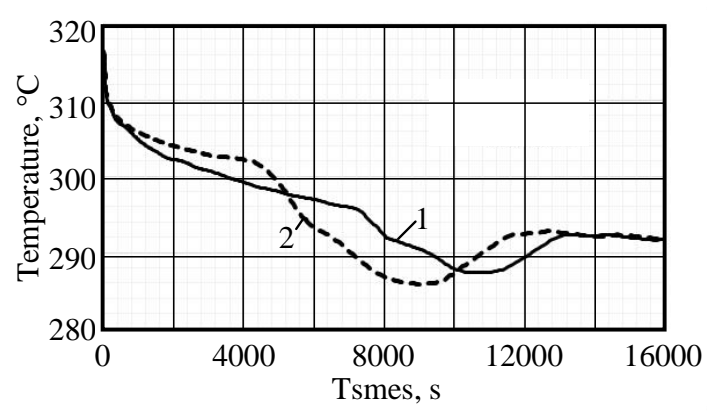

Fig. 2. Coolant temperature under the reactor lid: Scenario 1 (1); Scenario 2 (2)

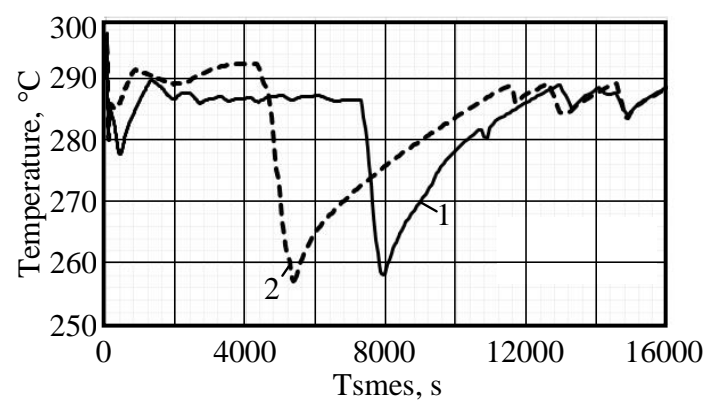

Fig. 4. Coolant temperature at the reactor bottom: Scenario 1 (1); Scenario 2 (2)

As can be seen from the graphs, uncontrolled movement of CR RCPS group from core accompanied by a significant temperature change in the reactor. The temperature changing reaches a value more $50{ }^{\circ} \mathrm{C}$ that may affect to the reactor elements strength.

CR RCPS ejection during the drive cover break

IE envisages the rapid CR movement from the initial position to the maximum top position. Ejection can occur due to CR mechanism cover rupture and is accompanied by leak initiating from the reactor with equivalent diameter $55 \mathrm{~mm}[8,9,10]$. If we assume the ejection of all cover internal elements (drive, electric cables, etc.), then equivalent leak diameter increases to $85 \mathrm{~mm}$. Given such uncertainty for this mode we considered two limiting cases: scenario 1 with an equivalent leak diameter $55 \mathrm{~mm}$ and Scenario 2 with diameter $85 \mathrm{~mm}$.

During unit work cover rupture in modes "On power" or "Minimal controlled power level" leads to short neutron power jump, but a significant increase thermal power is not observed, because the jump compensated by SCRAM, so mode "hot shutdown" selected for the calculation analysis.

In case of the cover rupture in a mode "hot shutdown" the CR RCPS ejection does not increase thermal power, as CR entered in core and in primary coolant formed boric acid stop concentration formed.

Also, it should be noted that the IE progress at the mode "On power" is less conservative than "hot shutdown", because after SCRAM increased residual energy level provides significant additional coolant heater and therefore prevents the reactor and internals cooling.

Figure 5-8 show pressure and temperature graphs in reactor volumes for the two analyzed scenarios. 


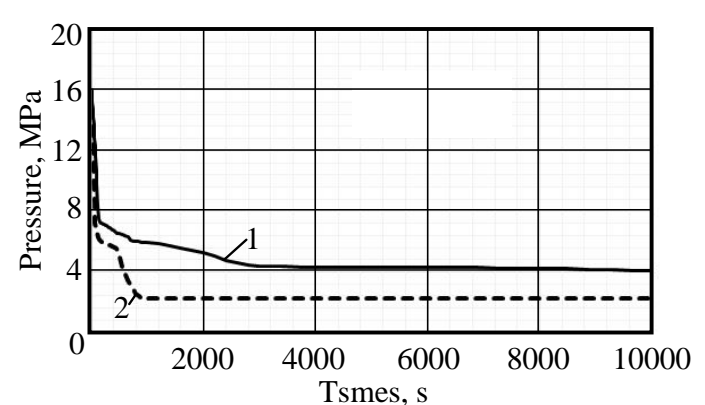

Fig. 5. Coolant pressure under the reactor lid: Scenario 1 (1); Scenario 2 (2)

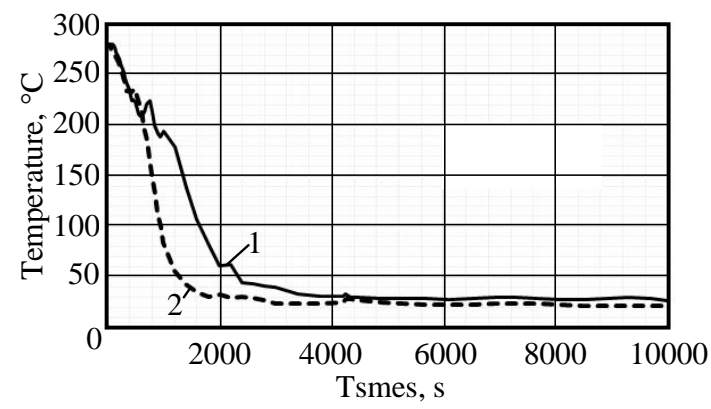

Fig. 7. Coolant temperature at the reactor outlet: Scenario 1 (1); Scenario 2 (2)

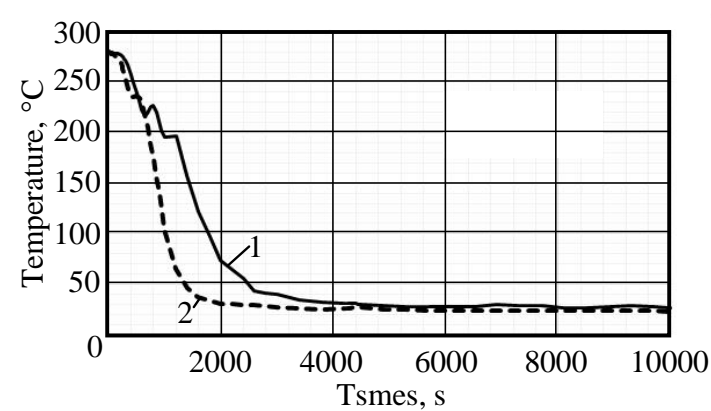

Fig. 6. Coolant temperature under the reactor lid: Scenario 1 (1); Scenario 2 (2)

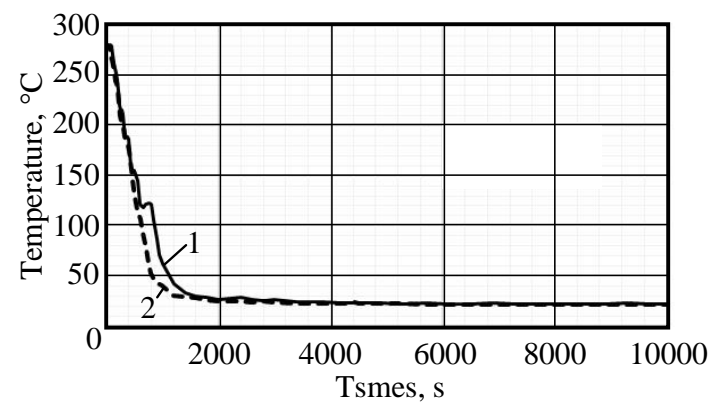

Fig. 8. Coolant temperature at the reactor bottom: Scenario 1 (1); Scenario 2 (2)

As can be seen from the graphs, CR RCPS ejection at the drive cover rupture accompanied by a significant temperature change in the reactor. The temperature changing reaches a value more $250{ }^{\circ} \mathrm{C}$ that definitely affect to the reactor elements strength.

Analysis results. The calculation analysis results for the regulatory modes 2.5 "Uncontrolled CR RCPS movement from the core" and modes 3.6 "CR RCPS ejection during the drive cover break" shown in Figure 1 - 8.

Calculation analysis showed that the progress modes are accompanied by a significant temperature decrease of the reactor coolant to more than $50{ }^{\circ} \mathrm{C}$ and $250{ }^{\circ} \mathrm{C}$ for modes 2.5 and 3.6 respectively. Thus, modes have sufficient importance and their impact should be assessed as part of life extension of reactor type VVER-1000.

However, a final conclusion about the impact of these modes can be made only after strength evaluation, which, according to the above calculations prepared BC in a reactor (pressure, temperature and heat transfer coefficient) to be used for the strength analysis.

Conclusions. In this article we made calculation analysis of modes with uncontrollable CR RCPS movement and ejection for strength assessing of RPV and reactor internals, which had not analyzed quantitatively previously as part of life extension of reactors VVER-1000 in Ukraine. To perform the calculation analysis we used actual thermal hydraulic model of unit №3 of RNPP for computer code RELAP5/MOD3.2. As a result, we made the conclusion about importance of these modes and the need to use the research results for the strength analysis, results of which can be present in the next publication.

\section{Література}

1. Pressurized Thermal Shock in Nuclear Power Plants: Good Practices for Assessment. Deterministic Evaluation for the Integrity of Reactor Pressure Vessel. IAEA-TECDOC-1627. - Vienna: IAEA, 2010.

2. ПМ-Т.0.03.415-16. Типова програма оцінки технічного стану та продовження терміну експлуатації корпусів, верхніх блоків і головних роз'ємів реакторів енергоблоків ВВЕР-1000 / ДП НАЕК. «Енергоатом». - Київ, 2016. 
3. Рівненська АЕС. Енергоблок № 3. Опис розрахункової теплогідравлічної моделі енергоблоку № 3 ВП РАЕС для комп'ютерного коду Relap5/Mod3.2. 191-77-OTC-15. / НTК «IE3 ім. Є.О. Патона ». - Київ, 2015.

4. Типовий технологічний регламент безпечної експлуатації енергоблоків АЕС з реакторами ВВЕР1000. РГ-Б.0.03.179-13. / ДП НАЕК «Енергоатом». - Київ, 2013.

5. Технологічний регламент безпечної експлуатації енергоблоку №3 Рівненської АЕС. 3-P-PAEC. / ВП РАЕС ДП НАЕК «Енергоатом». - Вараш, 2016.

6. American National Standard for Decay Heat Power in Light Water Reactors. ANSI/ANS-5.1-1979. / American Nuclear Society Standards Committee. Working Group ANS-5.1. - Illinois, 1979.

7. Рівненська АЕС. Енергоблок № 3. Звіт з аналізу безпеки. Глава 4. Аналіз проектних аварій. База даних по ЯПВУ. 22.3.133.ОБ.01.03. / ТОВ «Атоменергосервіс». - Київ, 2013.

8. Реакторна установка В-320. Технічний опис та інформація з безпеки. 320.00.00.00.000 Д61. / ОКБ «Гідропрес». - Подольск, 1987.

9. Рівненська АЕС. Енергоблок №3. Звіт з аналізу безпеки. Глава 4. Аналіз проектних аварій. Частина 1. Результати аналізу проектних аварій. Книга 2. Аналіз вихідних подій. Частина 3. 22.3.133.ОБ.01.02.03. / ТОВ «Атоменергосервіс». - Київ, 2013.

10. Реактор. Креслення загального вигляду. 320.06.00.00.000 ВО. / ОКБ «Гідропрес». - Подольск, 1987.

\section{References}

1. Pressurized Thermal Shock in Nuclear Power Plants: Good Practices for Assessment. Deterministic Evaluation for the Integrity of Reactor Pressure Vessel. (2010). IAEA-TECDOC-1627. - Vienna: IAEA.

2. PM-T.0.03.415-16. Typova prohrama otsinky tekhnichnoho stanu ta prodovzhennya terminu ekspluatatsiyi korpusiv, verkhnikh blokiv i holovnykh roz'yemiv reaktoriv enerhoblokiv VVER-1000 [PMT.0.03.415-16. A typical program of technical condition assessment and life extension of vessels, the upper blocks and the main connector of reactors VVER-1000 reactors]. (2013). SE "Energoatom" NNEGC. Kyiv.

3. Rivnens'ka AES. Enerhoblok № 3. Opys rozrakhunkovoyi teplohidravlichnoyi modeli enerhobloku №3 VP RAES dlya komp'yuternoho kodu Relap5/Mod 3.2. 191-77-OT·S-15 [Rivne NPP. Unit 3.Description of the thermal-hydraulic calculation model of Rivne NPP unit №3 for computer code Relap5/Mod3.2.191-77-OTC-15]. (2015). STC “Electric Welding Institute behalf of Paton”. Kyiv.

4. Typovyy tekhnolohichnyy rehlament bezpechnoyi ekspluatatsiyi enerhoblokiv AES z reaktoramy VVER1000. RH-B.0.03.179-13 [Typical technological regulation of NPP with VVER-1000 reactors safe operation. RG-B.0.03.179-13]. (2013). SE “Energoatom” NNEGC. Kyiv.

5. Tekhnolohichnyy rehlament bezpechnoyi ekspluatatsiyi enerhobloku №3 Rivnens'koyi AES. 3-R-RAES [Technological regulation of RNPP Unit 3 safe operation. 3-R-RAES]. (2016). SS RNPP SE "Energoatom” NNEGC. Varash.

6. American National Standard for Decay Heat Power in Light Water Reactors. (1979). ANSI/ANS-5.11979. American Nuclear Society Standards Committee.Working Group ANS-5.1. Illinois.

7. Rivnens'ka AES. Enerhoblok № 3. Zvit z analizu bezpeky. Hlava 4. Analiz proektnykh avariy. Baza danykh po YAPVU. 22.3.133.OB.01.03. [Rivne NPP. Unit 3.Safety Analysis Report. Chapter 4: Analysis of design basis accidents. Data base for NSSS. 22.3.133.OB.01.03.]. (2013). Atomenergoservice Ltd. Kyiv.

8. Reaktorna ustanovka V-320. Tekhnichnyy opys ta informatsiya z bezpeky. 320.00.00.00.000 D61. [Reactor facility V-320. Technical description and safety information.320.00.00.00.000 D61]. (1987). OKB "Gidropress". Podolsk.

9. Rivnens'ka AES. Enerhoblok №3. Zvit z analizu bezpeky. Hlava 4. Analiz proektnykh avariy. Chastyna 1. Rezul'taty analizu proektnykh avariy. Knyha 2. Analiz vykhidnykh podiy. Chastyna 3. 22.3.133.OB.01.02.03. [Rivne NPP. Unit №3.Safety Analysis Report. Chapter 4: Analysis of design basis accidents. Part 1.Results of the design basis accidents analysis.Book 2.Analysis of the initial events.Part 3. 22.3.133.OB.01.02.03]. (2013). Atomenergoservice Ltd. Kiev.

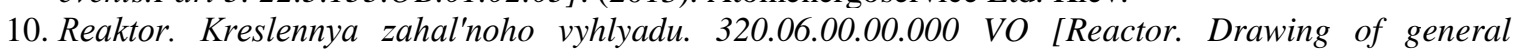
form.320.06.00.00.000 BO]. (1987). OKB “Gidropress”. Podolsk. 